\title{
Pelatihan Pengolahan Granul Instan Jahe Emprit dan Kapulaga Bagi Tim PKK Desa Kaliputih Kabupaten Banyumas
}

\author{
Arini Syarifah ${ }^{1 *}$, Hariyanti $^{1}$, Nur Isna Inayati ${ }^{2}$ \\ ${ }^{1}$ Fakultas Farmasi Universitas Muhammadiyah Purwokerto \\ ${ }^{2}$ Fakultas Ekonomi dan Bisnis Universitas Muhammadiyah Purwokerto \\ Jl. KH. Ahmad Dahlan Dusun III Kec. Kembaran Kabupaten Banyumas \\ Jawa Tengah 53182 \\ "E-mail : arinisyarifah29@gmail.com
}

DOI: https://doi.org/10.21107/pangabdhi.v6i2.7620

Naskah diterima 19 Juni 2020, Revisi 18 Agustus 2020, Terbit 29 Oktober 2020

\begin{abstract}
Abstrak
Jahe emprit dan kapulaga merupakan hasil pertanian para petani di desa Kaliputih kecamatan Purwojati kabupaten Banyumas. Jahe emprit merupakan komoditi hasil pertanian yang minoritas di desa kaliputih. Kapulaga dan jahe emprit juga hanya sebatas dijual dalam bentuk utuh tanpa proses pengolahan apapun. Oleh karena itu perlu adanya pelatihan pengolahan kombinasi jahe emprit dan kapulaga menjadi granul instan bertujuan untuk meningkatkan nilai jual dari kedua bahan tersebut. Ibu rumah tangga yang tergabung dalam Tim PKK desa Kaliputih merupakan mitra sasaran dalam pengabdian ini. Ibu rumah tangga merupakan segmentasi massa dengan peluang besar dalam pengolahan granul instan jahe emprit dan kapulaga dikarenakan rata-rata ibu-ibu di desa kaliputih menjadi ibu rumah tangga. Dari hasil pengabdian ini terjadi peningkatan pengetahuan dan ketrampilan Tim PKK desa Kaliputih dalam pengolahan jahe emprit dan kapulaga menjadi granul instan. Sehingga bisa disimpulkan Tim PKK desa Kaliputih sudah terlatih dalam pembuatan granul instan jahe emprit dan kapulaga.
\end{abstract}

Kata Kunci: granul instan, jahe emprit, kapulaga, pelatihan, Tim PKK

\begin{abstract}
Small gingers and cardamoms are agricultural products of farmers in Kaliputih village, Purwojati district, Banyumas regency. Small gingers are a minority agricultural commodity in the Kaliputih village. Small gingers and cardamom are also limited to being sold as whole without any processing. Therefore there are need for training in the processing granul instan with using combination of small gingers and cardamoms. The aim of this community services is to increase the selling value of both ingredients. Housewives, who are members of Empowerment Of Family Prosperity (PKK), are segmentation with great opportunity in processing instan granul of small gingers and cardamoms. The results of this community devotion is occur increase knowledge and skills of processing granul instant in PKK Team. So it can be concluded that PKK Team in the Kaliputih Village has been trained in the processing of granul instant small gingers and cardamom.
\end{abstract}

Key Words : granul instant, small ginger, cardamom, training, empowerment of family prosperity team

\section{PENDAHULUAN}

Desa Kaliputih merupakan desa yang memiliki luas 354.900 dengan jumlah penduduk 1900. Mayoritas penduduk desa Kaliputih bekerja sebagai petani. Hasil pertanian para petani di desa kaliputih berupa padi, jagung, kacang hijau, kacang kedelai, kapulaga dan salah satunya jahe emprit. Jahe emprit merupakan komoditi hasil pertanian yang minoritas. Hanya beberapa petani yang menanam tanaman jahe emprit. Hal tersebut dikarenakan nilai jual jahe emprit kurang menguntungkan dibandingkan komoditi pertanian yang lain. Kurangnya air di musim kemarau menjadi salah satu kendala para petani enggan menanam jahe karena lahan akan menjadi kering dan jahe akan meranggas daunnya. Hal itu menyebabkan panen jahe emprit berkurang. Rata-rata dalam setengah tahun, petani tersebut dapat memanen $100 \mathrm{~kg}$.

Jahe emprit memiliki banyak khasiat antara lain sebagai campuran obat tradisional terutama sebagai karminatif dan stimulan, penambah nafsu makan, tonik lambung, peluruh dahak, peluruh haid, pencegah mual, penurun tekanan darah, 
menghilangkan lelah, meningkatkan stamina, mencegah infeksi pada luka (Restiani, 2009). Jahe mempunyai komponen volatil (minyak atsiri) dan nonvolatil (oleoresin) yang paling tinggi dibandingkan jenis jahe yang lain (Panjaitan, 2012). Jahe mengandung minyak atsiri sebanyak 1,5-3,8\% dari berat keringnya. Sehingga cocok jika diekstrak baik minyak atsri ataupun oleoresinnya. Ekstrak jahe emprit mengandung senyawa gingerol, shogaol dan zingerone yang mempunyai aktivitas sebagai antioksidan, antiinflamasi, analgesik dan antikarsinogenik (Yessi, dkk, 2017).

Desa Kaliputih juga memiliki petani kapulaga. Setiap tahun kapulaga yang berhasil dipanen $400 \mathrm{~kg}$. Dalam hal ini kapulaga juga hanya sebatas dijual dalam bentuk utuh tanpa proses pengolahan apapun. Biji kapulaga mengandung minyak atsiri sebesar 3-7\% yang terdiri terpeneol, terpeneolasetat, sineol, borneol dan kanfer yang berfungsi untuk mengencerkan dahak, memudahkan mengeluarkan air dari perut, menghangatkan dan membersihkan darah, analgetik, mengharumkan, stimulan dan pemberi aroma (Tambunan, 2017). Oleh karena itu dengan adanya manfaat dari jahe emprit dan kapulaga maka perlu adanya pelatihan pengolahan kombinasi jahe emprit dan kapulaga menjadi granul instan untuk meningkatkan nilai jual dari kedua bahan tersebut. Granul instan merupakan bentuk sediaan makanan yang disajikan secara menarik dan praktis (Husni, 2020).

Ibu rumah tangga merupakan segmentasi massa dengan peluang besar dalam pengolahan granul instan jahe emprit dan kapulaga dikarenakan rata-rata ibu-ibu di desa kaliputih menjadi ibu rumah tangga. Komunitas para ibu ini biasanya diwadahi oleh organisasi yang disebut Pemberdayaan dan Kesejahteraan Keluarga (PKK). Adanya pengolahan granul instan jahe emprit dan kapulaga diharapkan dapat meningkatkan ekonomi masyarakat sekitar terutama pada ibu rumah tangga dan petani di Desa Kaliputih Kecamatan Purwojati Kabupaten Banyumas.

\section{METODE}

Kegiatan pengabdian dilaksanakan pada tanggal 1 Maret 2020 dan bertempat di Balai Desa Kaliputih Kecamatan Purwojati Kabupaten Banyumas. Kelompok sasaran dalam pengabdian ini adalah Tim PKK Desa Kaliputih. Metode yang dilakukan dalam pengabdian ini adalah dengan metode pembelajaran kombinasi antara metode ceramah, diskusi dan pelatihan. Menurut Roestiyah (2008) ceramah adalah pembelajaran mengenai suatu masalah yang disampaikan secara lisan. Metode diskusi merupakan metode penyampaian suatu maslah yang harus dipecahkan oleh penerima dan pemberi materi (Saktyowati, 2010). Dikombinasikan dengan metode latihan atau disebut juga metode training agar mitra memperoleh suatu ketangkasan, ketepatan, kesempatan, dan keterampilan khusunya dalam pembuatan granul instan (Djamarah, 2010). Menurut Dyanesilia (2012) Metode ceramah dan diskusi dianggap sangat efektif apabila materi yang harus dikuasai penerima materi cukup luas, sementara itu waktu yang dimiliki terbatas.

Metode ini dijabarkan dalam beberapa tahap. Tahap yang pertama pretest. Pretest dilakukan untuk mengetahui tingkat pemahaman Tim PKK sebelum pemberian materi. Tahap yang kedua adalah presentasi dan diskusi. Materi dipresentasikan oleh Tim Pengabdian khususnya dari Dosen Fakultas Farmasi UMP. Setelah pemberian materi kemudian dilanjutkan dengan kegiatan diskusi. Tahap yang ketiga adalah praktek pembuatan granul instan jahe emprit dan kapulaga. Tim PKK desa Kaliputih mempraktekan cara pembuatan granul instan jahe emprit-kapulaga didampingi oleh Tim Pengabdian UMP. Tahap yang keempat adalah posttest. Postest dilakukan untuk mengetahui tingkat pemahaman Tim PKK setelah pemberian materi dan pelatihan.

Bahan yang digunakan dalam pengabdian ini adalah bahan granul instan (jahe emprit, kapulaga, gula pasir, gula merah dan air) dan soal pretest-postest. Alat yang digunakan dalam pengabdian ini adalah food processor, kompor, wajan dan ayakan ukuran 10 mesh.

\section{Pengambilan Data}

Pengambilan data yang dilakukan dalam pengabdian ini adalah demografi peserta dan data hasil pretest dan posttest. Pengambilan data demografi peserta dalam pengabdian ini menggunakan kuesioner. Kuesioner berisi data usia, pekerjaan, dan pendidikan. Data hasil pretest dan posttest dihitung berdasarkan skoring untuk jawaban betul dan salah. Skor 1 untuk 
jawaban yang betul dan skor 0 untuk jawaban yang salah. Kemudian disetiap nomor dilakukan analisis apakah ada peningkatan atau tidak antara hasil pre-test dengan hasil post-test.

\section{HASIL DAN PEMBAHASAN}

Kegiatan pengabdian dilaksanakan di Balai Desa Kaliputih Kecamatan Purwojati Kabupaten Banyumas. Materi yang disampaikan adalah mengenai ciri-ciri jahe emprit, manfaat jahe emprit dan kapulaga, produk granul, dan cara pembuatan granul (Gambar 1).

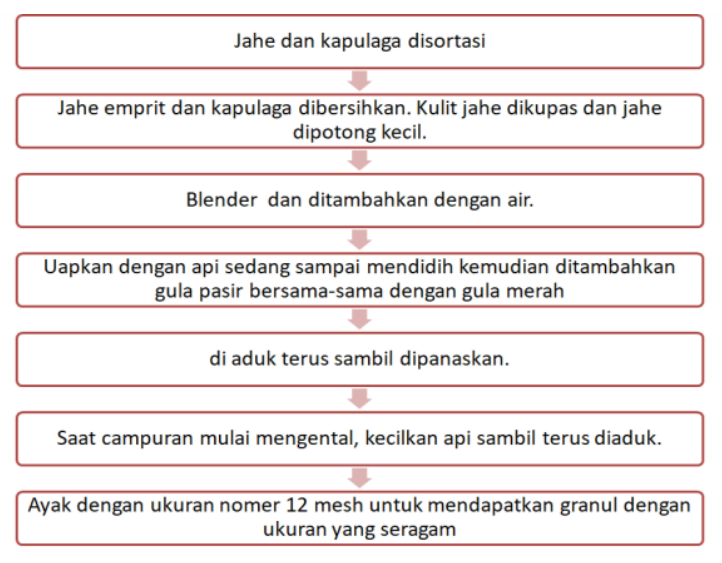

Gambar 1. Alur Pembuatan Granul Jahe Emprit

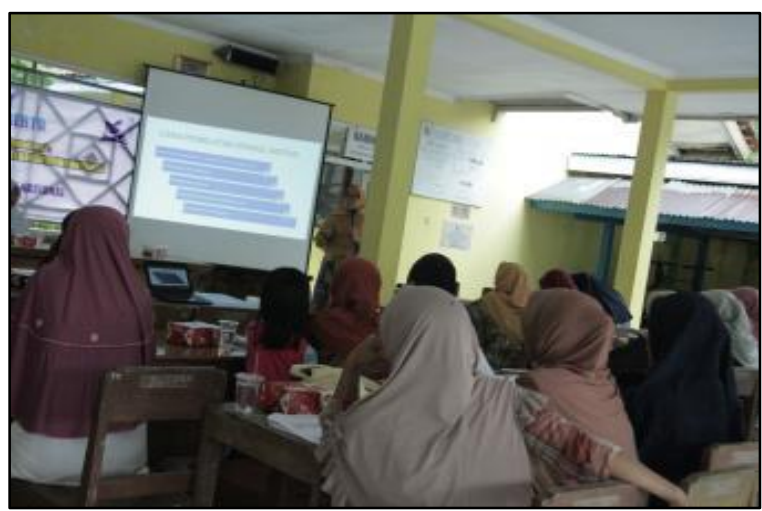

Gambar 2. Penyampaian Materi Pelatihan

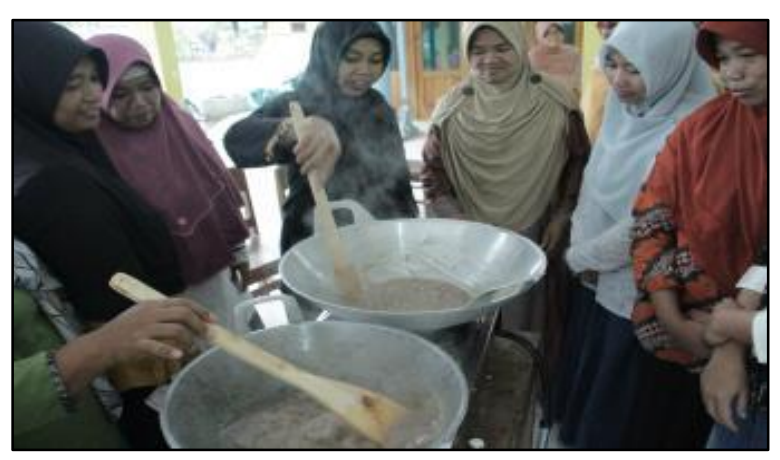

Gambar 3. Praktek Pembuatan Granul Jahe Emprit oleh Peserta

\section{Karakteristik Peserta}

Pengkategorian karakteristik umur dikategorikan sesuai dengan petunjuk dari Departemen Kesehatan (2009). Dari Tabel 1 dapat dilihat bahwa dari 18 peserta yang paling besar adalah usia dewasa $72 \%$ (13 orang). Menurut Kotler (2006) usia merupakan salah satu faktor dalam menentukan penilaian seseorang. Biasanya peserta pada usia produktif memiliki tingkat pengetahuan yang lebih luas dibandingkan peserta lansia. Hal ini akan berdampak pada pemahaman peserta saat materi diberikan. Data usia juga berkaitan dengan data pekerjaan yang terdapat pada Tabel 2 .

Tabel 1. Karakteristik Umur Peserta

\begin{tabular}{cccc}
\hline Keterangan & Kategori & Jumlah & Presentase \\
\hline Usia dewasa & $\begin{array}{c}26-45 \\
\text { tahun }\end{array}$ & $\begin{array}{c}13 \\
\text { orang }\end{array}$ & $72 \%$ \\
Usia lansia & $\begin{array}{c}46-65 \\
\text { tahun }\end{array}$ & 5 orang & $28 \%$ \\
\hline
\end{tabular}

Tabel 2. Karakteristik Pekerjaan Peserta

\begin{tabular}{ccc}
\hline Pekerjaan & Jumlah & Presentase \% \\
\hline $\begin{array}{c}\text { Ibu Rumah } \\
\text { Tangga } \\
\text { Petani }\end{array}$ & 15 orang & 83,33 \\
1 orang & 5,56 \\
Guru Honorer & 1 orang & 5,56 \\
Pedagang & 1 orang & 5,56 \\
\hline
\end{tabular}

Tabel 3. Karakteristik Pendidikan Peserta

\begin{tabular}{ccc}
\hline Pendidikan & Jumlah & Presentase \% \\
\hline Sekolah Dasar & 3 orang & 16,67 \\
Sekolah & & \\
Menengah & 7 orang & 38,89 \\
$\begin{array}{c}\text { Pertama } \\
\text { Sekolah }\end{array}$ & 7 orang & 38,89 \\
Menengah Atas & \\
Sarjana & 1 orang & 5,56
\end{tabular}

Status pekerjaan merupakan salah satu faktor yang dapat mempengaruhi perilaku seseorang (Notoatmodjo, 2007). Dari Tabel 2 peserta 
sebagian besar adalah ibu rumah tangga $(83,33 \%)$. Ibu rumah tangga merupakan target pengabdian pembuatan granul instan jahe emprit karena memiliki waktu luang yang bisa dimanfaatkan untuk membuat granul instan jahe emprit kapulaga dan juga dapat menambah pendapatan ibu rumah tangga.

Pendidikan dapat meningkatkan kemampuan pemahaman, pengorganisasian dan perilaku seseorang (Dimyanti dan Mudjiono, 2009). Dari Tabel 3 didapatkan data bahwa pendidikan responden terbanyak adalah sekolah menengah pertama (SMP) dan sekolah menengah atas (SMA).

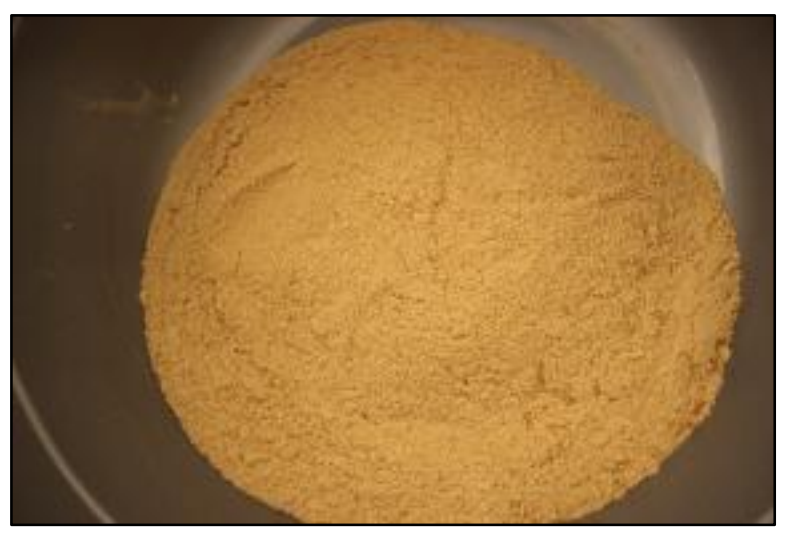

Gambar 4. Hasil Pengolahan Granul Instan

\section{Analisis Peserta Sebelum dan Sesudah Pemberian Materi}

Penilaian kuisoner dilakukan dengan membandingkan pertanyaan yang benar di setiap nomer dengan total soal kemudian dikalikan dengan $100 \%$. Setelah dihitung persentase jumlah dan dimasukkan ke dalam kriteria objektif meliputi : 80-100 \% kategori baik, 60$79 \%$ kategori cukup, dan $\leq 60 \%$ kategori kurang. Tabel 4. Hasil Penilaian Pre Test dan Post Test

\begin{tabular}{lcccc} 
& \multicolumn{2}{c}{ Pretest } & \multicolumn{2}{c}{ Postest } \\
\cline { 2 - 5 } Pertanyaan & $\begin{array}{c}\% \\
\text { Jawaban } \\
\text { Benar }\end{array}$ & $\begin{array}{c}\text { Katego } \\
\text { ri }\end{array}$ & $\begin{array}{c}\text { Jawab } \\
\text { an } \\
\text { Benar }\end{array}$ & $\begin{array}{c}\text { Katego } \\
\text { ri }\end{array}$ \\
\hline $\begin{array}{l}\text { Ciri jahe emprit } \\
\text { Kandungan } \\
\text { jahe emprit }\end{array}$ & 100 & Baik & 100 & Baik \\
$\begin{array}{l}\text { Manfaat } \\
\text { emprit }\end{array}$ & 77,78 & Cukup & 100 & Baik \\
$\begin{array}{l}\text { Manfaat } \\
\text { kapulaga }\end{array}$ & 88,89 & Baik & 94,44 & Baik \\
\hline & 72,22 & Cukup & 94,44 & Baik \\
\hline
\end{tabular}

\begin{tabular}{|c|c|c|c|c|}
\hline \multirow[b]{2}{*}{ Pertanyaan } & \multicolumn{2}{|c|}{ Pretest } & \multicolumn{2}{|c|}{ Postest } \\
\hline & $\begin{array}{c}\% \\
\text { Jawaban } \\
\text { Benar }\end{array}$ & $\begin{array}{c}\text { Katego } \\
\text { ri }\end{array}$ & $\begin{array}{c}\% \\
\text { Jawab } \\
\text { an } \\
\text { Benar }\end{array}$ & $\begin{array}{c}\text { Katego } \\
\text { ri }\end{array}$ \\
\hline Ciri granul & 61,11 & Kurang & 83,33 & Baik \\
\hline $\begin{array}{l}\text { Penyusun } \\
\text { granul }\end{array}$ & 61,11 & Kurang & 100 & Baik \\
\hline $\begin{array}{l}\text { Cara } \\
\text { Pembuatan } \\
\text { Granul instan }\end{array}$ & 72,22 & Cukup & 88,89 & Baik \\
\hline
\end{tabular}

Dari hasil pretest pada Tabel 4 menunjukan bahwa ada 2 pertanyaan dijawab baik oleh peserta $(>80 \%)$. Namun mayoritas pengetahuan peserta dalam menjawab pertanyaan pretest dapat dikatakan kuran. Hal ini menunjukan bahwa peserta masih belum memahami mengenai pemanfaatan jahe emprit khususnya dalam pembuatan granul instan. Pada Tabel 4 juga menunjukan hasil postest. Semua pertanyaan dijawab baik oleh peserta pengabdian. Hal ini menunjukan metode yang digunakan dalam pengabdian ini efektif.

\section{KESIMPULAN}

Kesimpulan dari kegiatan ini adalah :

1. Kegiatan pelatihan pembuatan granul instan jahe emprit dan kapulaga disambut antusias oleh peserta.

2. Tim PKK berhasil membuat granul instan jahe emprit dan kapulaga

\section{UCAPAN TERIMA KASIH}

Tim pengabdian kepada masyarakat mengucapkan terima kasih kepada Kementerian Riset dan Teknologi / Badan Riset dan Inovasi Nasional yang berkontribusi dalam pengabdian ini.

\section{DAFTAR PUSTAKA}

Departemen Kesehatan RI. 2009. Sistem Kesehatan Nasional. Jakarta

Dimyanti \& Mudjiono. 2009. Belajar dan Pembelajaran. Jakarta: Rineka Cipta

Djamarah, S, B., Zain, A. 2006. Strategi Belajar Mengajar. Jakarta: Rineka Cipta.

Dyanesilia, A. 2012. Metode Pembelajaran Ceramah Plus. Online. Tersedia di http://hardipisan.blogspot.com/\#uds-search- 
results [diakses 8-05-2020].

Febriani, Y., Hesti, R., Winingsih, W., Aulifa, Diah Lia., \& Permatasari, A. 2018. Potensi Pemanfaatan Ampas Jahe Merah (Zingiber officinale Roscoe) sebagai Obat Analgetik. Indonesian Journal of Pharmaceutical Science and Technology Vol 1(1). 57-64 pp.

Harahap, A.R., Efendi, R., \& Harun, N. 2016. Pemanfaatan Ekstrak Jahe Merah( Zingiber Officinale Var. Rubrum) dan Kulit Nanas (Ananas Comosus L. Mer) Dalam Pembuatan Bubuk Instan. Jurnal Online Mahasiswa (JOM) Bidang Pertanian. Vol 3(2). 1-16 pp

Husni, P., Fadhiilah, Luthfi, M., \& Hasanah, U. 2020. Formulasi Dan Uji Stabilitas Fisik Granul Instan Serbuk Kering Tangkai Genjer (Limnocharis Flava (L.) Buchenau.). Sebagai Suplemen Penambah Serat. Jurnal Ilmiah Farmasi Farmasyifa Vol (3) $1-8$ pp.

Kartikasari., R., Astuti, I. Y \& Hartanti, D. 2009. Formula Granul Instan Ekstrak Temulawak (Curcuma Xanthorriza Roxb) Dengan Kombinasi Gelatin Dan Dekstrin, Jurnal Pharmacy. Vol 06(02).86-99pp
Kotler, P., 2006, Manajemen Pemasaran, jilid I dan II, Edisi Kesebelas, Jakarta : PT. Indeks Garmedia

Notoatmodjo, S. 2007. Pendidikan dan Perilaku Kesehatan, Jakarta : Rineka Cipta

Panjaitan, E.S., Saragih, A., \& Purba, D. 2012. Formulasi Gel dari Ekstrak Rimpang Jahe Merah (Zingiber officinale Rosc.). Journal of Pharmaceutics and Pharmacology. Vol 1(1).9-20pp.

Restiani, K.D. 2009. Uji Efek Sediaan Serbuk Instan Rimpang Jahe (Zingiber officinale Roscoe) sebagai Tonikum Terhadap Mencit Jantan Galur Swiss Webster, Skripsi, Fak. Farmasi, Universitas Muhammadiyah Purwokerto

Roestiyah, K. N. 2008. Strategi Belajar Mengajar. Jakarta: Rineka Cipta.

Saktyowati, D. O. 2011. Meningkatkan Mutu Pendidik Dalam Pembelajaran Sains. Jakarta: CV. Ghina Walafafa

Tambunan, L,R. 2017. Isolasi dan Identifikasi Komposisi Minyak atsisri dari Biji Tanaman Kapulaga (Amomum Cardamomum Willd), Jurnal Kimia Riset. Vol 2(1). 57-60pp 